\title{
Semiotika Rambu-Rambu Lalu Lintas Laut
}

\author{
Surnata \\ Program Studi MTPD, Politeknik Transportasi Sungai, Danau, dan Penyeberangan Palembang \\ Email: natayuni@yahoo.com
}

Hayatun Nufus

(Corresponding Author)

Program Studi Pendidikan Bahasa Indonesia, Universitas PGRI Palembang

Email: hayatunsyamsul26@gmail.com

\section{Kodrat Alam}

Program Studi MTPD, Politeknik Transportasi Sungai, Danau, dan Penyeberangan Palembang Email: kodratalam78@gmail.com

\section{Elfita Agustini}

Politeknik Transportasi Sungai, Danau, dan Penyeberangan Palembang

Email: elfitaagustini@gmail.com

\begin{abstract}
APA Citation: Surnata, S., Nufus, H., Alam, K., \& Agustini, E. (2021). Semiotika Rambu-Rambu Lalu Lintas Laut. Silampari Bisa: Jurnal Penelitian Pendidikan Bahasa Indonesia, Daerah, dan Asing, 4(2), 443-456. https://doi.org/10.31540/silamparibisa.v4i2.1387
\end{abstract}

\begin{abstract}
Abstrak
Rambu lalu lintas adalah bagian dari perlengkapan jalan yang memuat lambang, huruf, angka, serta kalimat dan perpaduan di dalamnya dan berfungsi untuk memberikan peringatan, larangan, perintah, dan petunjuk bagi para pengguna jalan. Warna dan bentuk sebuah rambu lalu lintas mengandung makna yang tidak dipahami semua orang. Masalah dalam penelitian ini adalah "Bagaimanakah semiotika rambu-rambu lalu lintas pada sistem pelampung suar lateral dan pelampung suar kardinal?" Penelitian ini bertujuan untuk mengetahui dan mendeskripsikan sistem pelampung suar lateral dan pelampung suar kardinal. Metode yang digunakan oleh penulis pada penelitian ini adalah metode kualitatif. Hasil penelitian warna yang terdapat pada buoy cardinal dan lateral menunjukkan fungsi dan posisi buoy tersebut seperti warna pada tiang yang berwana kuning pada bagian dan hitam pada bagian bawah atau peletakan warna yang bervariasi. Warna hijau dan merah pada buoy lateral menunjukkan posisi tanda teresebut seperti kiri atau di posisi kanan kapal. Begitupun dengan bentuk cardinal lateral, jika pada bagian atas runcing berarti itu buoy yang berkedudukan di sebelah kanan, jika buoy lateral berbentuk tumpul artinya posisi buoy tersebut berada di sebelah kiri. Warna yang terdapat pada buoy cardinal dan lateral menunjukkan fungsi dan posisi buoy tersebut seperti warna pada tiang yang berwana kuning pada bagian dan hitam pada bagian bawah atau peletakan warna yang bervariasi. Warna hijau dan merah pada buoy lateral menunjukkan posisi tanda teresebut seperti kiri atau di posisi kanan kapal. Begitupun dengan bentuk cardinal lateral, jika pada bagian atas runcing berarti itu buoy yang
\end{abstract}


Surnata, Hayatun Nufus, Kodrat Alam, Elfita Agustini

Semiotika Rambu-Rambu Lalu Lintas Laut

berkedudukan di sebelah kanan, jika buoy lateral berbentuk tumpul artinya posisi buoy tersebut berada di sebelah kiri.

Kata kunci: semiotika, rambu lalu lintas laut, buoy kardinal, buoy lateral

\title{
Semiotics of Marine Traffic Signs
}

\begin{abstract}
Traffic signs are part of road equipment that contains symbols, letters, numbers, as well as sentences and combinations in them and serves to provide warnings, prohibitions, orders, and instructions for road users. The color and shape of a traffic sign contain meanings that are not understood by everyone. The problem in this study is "How is the semiotics of traffic signs in the lateral flare buoy system and cardinal beacon buoy?" This study aims to identify and describe the lateral and cardinal flare buoy systems. The method used by the author in this study is a qualitative method. The results of the color research on the cardinal and lateral buoys show the function and position of the buoy, such as the color on the pole which is yellow on the bottom and black on the bottom or the placement of various colors. The green and red colors on the lateral buoy indicate the position of the sign such as the left or the starboard position of the ship. Likewise with the lateral cardinal shape, if it is pointed at the top, it means that the buoy is on the right, if the lateral buoy is blunt, it means that the buoy is on the left. The colors found on the cardinal and lateral buoys indicate the function and position of the buoy, such as the color on the pole which is yellow on the bottom and black on the bottom or the placement of various colors. The green and red colors on the lateral buoy indicate the position of the sign such as the left or the starboard position of the ship. Likewise with the lateral cardinal shape, if it is pointed at the top, it means that the buoy is on the right, if the lateral buoy is blunt, it means that the buoy is on the left.
\end{abstract}

Keywords: semiotics, marine traffic signs, cardinal buoys, lateral buoys

\section{A. Pendahuluan}

Transportasi merupakan kebutuhan dasar manusia. Dalam berbagai kegiatan manusia tidak terlepas dari transportasi. Berbagai aktivitas manusia selalu berhubungan dengan transportasi (Saribanon, 2017). Jika diibaratkan mansia dan transportasi seperti sebuah perahu dan dayung, perahu tidak akan bergerak maju jika tanpa dayung. Dalam menggunakan moda transportasi dibutuhkan ramburambu lalu lintas. Rambu-rambu lalu lintas berfungsi untuk memberi arah kepada pengemudi mengenai kondisi lalu lintas yang akan ditempuh (Wahyuni, 2019).

Rambu lalu lintas adalah bagian dari perlengkapan jalan yang memuat lambang, huruf, angka, serta kalimat dan perpaduan di dalamnya dan berfungsi untuk memberikan peringatan, larangan, perintah dan petunjuk bagi para pengguna jalan (Syakur \& Anamisa, 2018; Saleh, 2018). Pengguna transportasi wajib memahami makna yang terkandung dalam rambu lalu lintas. Rambu lalu lintas telah diatur menurut Peraturan Menteri Perhubungan Nomor 13 tahun 2014. Pemahaman dengan makna-makna yang tertera dalam rambu-rambu lalu intas dapat menekan jumlah korban kecelakaan.

Dalam Peraturan Menteri Perhubungan Republik Indonesia Nomor 13 Tahun 2014 tentang Lalu Lintas Bab 1 Pasal 1 bahwa rambu lalu lintas adalah bagian perlengkapan jalan yang berupa lambang, huruf, angka, kalimat, dan/atau

Silampari Bisa: Jurnal Penelitian Pendidikan Bahasa Indonesia, Daerah, dan Asing Vol. 4, No. 2, 2021 
perpaduan yang berfungsi sebagai peringatan, larangan, perintah, atau petunjuk bagi pengguna jalan. Warna, bentuk, posisi, dan ketinggian dijelaskan dalam Permenhub ini. Selain itu, pemahaman akan makna setiap rambu-rambu lalu lintas sangat penting bagi pengguna jalan, sungai, dan laut, karena hal itu dapat menciptakan ketertiban dan mengurangi korban nyawa dalam kecelakaan berkendara.

Rambu-rambu lalu lintas itu unik, bahkan ada beberapa tanda yang terkandung sulit untuk dipahami maknanya. Guna mencoba memahami makna yang terkandung, maka penulis bermaksud untuk mencari dan menganalisis makna yang terkandung di dalam rambu-rambu lalu lintas tersebut. Pencarian makna tersebut akan menggunakan pendekatan semiotika yang terwujud dalam sebuah penelitian yang berjudul "Semiotika Rambu-Rambu Lalu lintas Laut".

Teori Semiotika Charles Sander Peirce, semiotika didasarkan pada logika, karena logika mempelajari bagaimana orang bernalar, sedangkan penalaran menurut Peirce dilakukan melalui tanda-tanda (dalam Rorong, 2019). Tanda-tanda ini menurut Peirce memungkinkan kita berpikir, berhubungan dengan orang lain dan memberi makna pada apa yang ditampilkan oleh alam semesta (dalam Herman, 2017).

Kata semiotik berasal dari kata semion (Yunani) yang berarti tanda. Di Eropa, Ferdinand de Saussure seorang ahli linguistik (1857--1913) dengan dasar linguistik mengembangkan konsep semiologi, sedangkan di Amerika Serikat, Charles Sanders Peirce (1834--1914) dengan pengertian yang sama mengembangkan konsep semiotika (semiotics). Selanjutnya, baik semiotika maupun semiologi dipergunakan dengan pengertian yang sama artinya (Ratih, 2016:2). Zaidan, dkk. (2007:160), menyatakan semiotik adalah cabang linguistik yang berkaitan dengan makna kata, terutama perubahan makna; studi hubungan antara kata dan hubungan antara bahasa, pikiran, dan tingkah laku serta bagaimana tingkah laku seseorang dipengaruhi oleh kata-kata yang diucapkan oleh orang lain.

Berdasarkan pendapat di atas dapat disimpulkan bahwa semiotik merupakan cabang linguistik yang berkaitan dengan makna kata dan secara sistematik mempelajari tanda-tanda dan lambang-lambang. Berkaitan dengan makna kata, terutama perubahan makna; studi hubungan antara kata dan hubungan antara bahasa, pikiran, dan tingkah laku serta bagaimana tingkah laku seseorang dipengaruhi oleh kata-kata yang diucapkan oleh orang lain.

Masalah dalam penelitian ini adalah "Bagaimanakah semiotik rambu-rambu lalu lintas pada sistem pelampung suar lateral dan pelampung suar kardinal?" Penelitian ini bertujuan untuk mengeathui dan mendeskripsikan makna bentuk dan warna rambu lalu lintas sistem pelampung suar lateral dan pelampung suar cardinal.

Menurut (Emzir \& Saifur, 2016:48) menyatakan semiotika atau semiologi adalah ilmu tentang tanda dan yang berasal dari kata "semion yang berarti tanda dan "logos" adalah sebuah ilmu. Agar pembelajaran kajian semiotika mencapai sasaraan, Pierch 1839-1914 (dalam Emzir \& Safir, 2016:49) mengemukakan ada tiga unsur semiotika atau yang biasa disebut teori segitga makna atau triangle meaning yang terdiri dari tiga elemen utama, yakni tanda, objek, dan interpretant. tanda adalah sesuatu yang berbentuk fisik yang dapat ditangkap oleh panca indra manusia dan merupakan sesuatu yang merujuk (mempresentasikan) hal-hal di luar tanda itu sendiri. Sementara interpretant atau pengguna tanda adalah konsep 
pemikiran dari orang yang menggunakan tanda dan menurunkanya ke maksud tertentu atau makna yang ada dalam benak seseorang tentang objek yang di rujuk dari sebuah tanda.

Semiotik merupakan kajian yang luas mengenai makna. Kajian ini menakup segala hal. Tradisi semiotik terdiri atas sekumpulan teori tentang bagaimana tandatanda merepresentasikan benda, ide, keadaan, situasi, perasaan, dan kondisi di luar tanda-tanda itu sendiri (Littlejohn, 2009:53). Semiotik bertujuan untuk mengetahui makna-makna yang terkandung dalam sebuah tanda atau menafsirkan makna tersebut sehingga diketahui bagaimana komunikator mengkonstruksi pesan. Konsep pemaknaan ini tidak terlepas dari perspektif atau nilai-nilai ideologis tertentu serta konsep kultural yang menjadi ranah pemikiran masyarakat di mana simbol tersebut diciptakan. Kode kultural yang menjadi salah satu faktor konstruksi makna dalam sebuah simbol menjadi aspek yang penting untuk mengetahui konstruksi pesan dalam tanda tersebut.

Istilah semiotika atau semiotik, yang dimunculkan pada akhir abad ke-19 oleh filsuf alrian pragmatik Amerika, Charles Sanders Pierce, merujuk kepada "doktrin formal tentang tanda-tanda". "Yang menjadi dasar semiotika adalah konsep tentang tanda: tak hanya bahasa dan sistem komunikasi yang tersusun oleh tandatanda, menjalin dunia itu sendiripun sejauh terkait dengan pikiran manusia seluruhnya terdiri atas tanda-tanda karena, jika tidak begitu manusia tidak akan bisa menjalin hubungannya dengan realitas" (Sobur, 2004:13). Semiotika sebagai cabang keilmuan yang memperlihatkan pengaruh yang semakin kuat dan luas, signifikasi semiotika tidak haja saja sebagai metode kajian (decoding), tetapi juga sebagai metode penciptaan (encoding). Sebagai metode kajian semiotika memperlihatkan kekuatannya di dalam berbagai bidang, seperti antropologi, politik, kajian keagamaan, media studies, dan kultural studi. Secara etimologis, istilah semiotik berasal dari kata Yunani semeoin yang berarti "tanda" itu sendiri didefinisikan sebagai sesuatu yang atas dasar konvensi sosial yang terbangun sebelumnnya, dapat dianggap mewakili sesuatu yang lain" (Sobur, 2004:95). Semiotika komunikasi dan tanda tidak dapat dipisahkan karena tanda merupakan bagian dari pesan yang disampaikan oleh komunikator kepada komunikan. Semiotika sebagai suatu model dari ilmu pengetahuan sosial memahami dunia sebagai suatu sistem hubungan yang memiliki unit dasar dengan tanda, maka dari itu menurut Peirce tanda terdiri atas simbol, ikon, dan indeks. Simbol adalah tanda yang tidak menunjukan hubungan alamiah antara pertanda dan penandaanya. Simbol atau lambing biasanya berbentuk verbal dan nonverbal objek yang disepakati. Ikon (hubungan antara tanda dengan objek) adalah hubungan petanda dan penandanya bersifat almiah dan bersamaan atau tanda yang muncul dari perwakilan fisik. Indeks adalah hubungan antara tanda dan penanda muncul secara ilmiah dari hubungan sebab akibat, contohnya menguap, artinya ngantuk.

Saussure, 1993:82 dalam (Nazaruddin, 2015:3) menyatakan semiotika adalah ilmu yang menelaah peran tanda sebagai bagian dari kehidupan sosial, ilmu ini meneliti hakikat tanda dan hukum yang mengatur tanda. Dengan kata lain, tanda memiliki fungsi dan makna sosial. Selanjutnya secara logika, masuk akal apabila kita katakan bahwa semiotika, yang mempelajari tanda sebagaimana baru saja dipaparkan, memiliki juga fungsi dan makna sosial.

Istilah semiotika berasal dari kata Yunani, Semeion, yang berarti tanda atau dari kata semeiotikos, yang berarti teori atau tanda (Rusmana, 2014:19). Semiotika 
juga berasal dari bahasa Yunani semeitikos yang artinya para penafsir tanda (Nazaruddin, 2015:3).

Eco 1923 (dalam Emzir \& Saifur, 2016:51) mengatakan semiotika menyangkut tidak hanya mengenai apa yang diungkapkan oleh tanda-tanda di dalam ucapan sehari-hari, tetapi lebih kepada 'apa' yang berada di balik sesuatu yang lain. Artinya semiotika itu bisa berupa kata, image, bunyi, bahasa tubuh, bunyi, gerak tubuh atau bahasa tubuh, dan benda.

Berdasarkan pengertian di atas peneliti dapat menyimpulkan bahwa semiotika adalah ilmu yang mempelajari tentang tanda, simbol, dan indeks. Dimana ketiganya merupakan bagian dari unsur semiotika yang digunakan untuk menganalisis dan menfsirkan sesuatu yang berbentuk sebuah karya sastra seperti puisi, pantun, dan mantra, sedangkan dalam bidang bahasa yaitu bahasa verbal seperti bahasa lisan dan nonverbal berupa bahasa tubuh. Berdasarkan UndangUndang 22 Tahun 2009 tentang Lalu Lintas dan Angkutan Jalan dinyatakan bahwa rambu lalu lintas adalah bagian perlengkapan Jalan yang berupa lambang, huruf, angka, kalimat, dan/atau perpaduan yang berfungsi sebagai peringatan, larangan, perintah, atau petunjuk bagi pengguna jalan. Rambu lalu lintas merupakan alat pengendali lalu lintas untuk menyampaikan informasi berupa peringatan, larangan, perintah, atau petunjuk dengan tujuan untuk menjaga keamanan, ketertiban, kelancaran, dan kenyamanan bagi pengguna jalan.

Terdapat beberepa jenis rambu lalu lintas yang sesuai kebutuhan dan fungsinya, sebagai berikut.

a. Perintah, yaitu bentuk pengaturan yang jelas dan tegas tanpa ada arti dan interpretasi lain kecuali yang disampaikan oleh rambu larangan tersebut. Karena sifatnya perintah, maka tidak benar jika ada interpretasi lain. Semua perintah rambu tersebut harus dipatuhi oleh pengguna jalan.

b. Larangan, yaitu bentuk pengaturan yang jelas dan tegas. Sama halnya dengan rambu perintah, rambu larangan merupakan rambu yang berfungsi untuk melarang setiap pengguna jalan untuk melakukan suatu tindakantindakan di dalam ruang lalu lintas jalan, seperti dilarang parkir, dilarang berhenti, dan lainnya.

c. Peringatan, menunjukkan kemungkinan adanya bahaya atau hal-hal yang harus diwaspadai oleh pengguna jalan.

d. Anjuran, bentuk pengaturan yang merupakan himbauan yang boleh ataupun tidak dilakukan oleh pengguna jalan.

e. Petunjuk, merupakan rambu panduan bagi para pengguna jalan, seperti rambu petunjuk arah, jurusan, jarak, kondisi lokasi, tempat beribadah, rumah makan, dan lainnya.

Jenis tanda rambu-rambu laut sebagai berikut.

1. Tanda Bunyi Rambu Laut

Rambu laut yang mengeluarkan tanda berupa bunyi ini sebenarnya merupakan alternatif bila keadaan cuaca di laut berkabut saat badai. Untuk suara bunyi berupa suara bel, gong, whistle, dan klingons agar anda mengetahui tanda dari rambu serta arti dan maksud dan tujuan rambu laut dibuat baik untuk kepentingan rambu lalu lintas pelayaran untuk keselamatan juga bagi pengawasan. 2. Tanda Lampu Suar Rambu Laut

Untuk lampu suar sebagai rambu laut yang memiiliki tanda warna dan cahaya atau sinar lampu juga berkedip atau cerlang (blink) merupakan tanda yang memiliki 
arti. Lampu suar selalu digunakan baik pada pelampung suar atau sering ditemukan pada menara lampu suar pelabuhan atau mercusuar. Cara membaca lampu suar khususnya merupakan syarat mutlak yang harus dikuasai pelaut atau nakhoda kapal untuk memperoleh sertifikasi atau surat izin mengendarai seperti layaknya SIM bila anda berkendara di jalan.

3. Tanda Warna Rambu Suar

Warna yang digunakan pada rambu navigasi laut secara umum mengunakan warna terang atau kontras mulai dari warna kuning, merah, hijau, hitam, dan putih. Rambu suar laut memiliki beberapa jenis yang memiliki fungsi baik secara khusus dan secara umum sebagai rambu navigasi laut. Untuk rambu laut dengan warna serta arti dari tanda atau kode tersebut lebih jelasnya anda dapat temukan pada bouy dan fungsinya.

\section{B. Metode Penelitian}

Penelitian ini bertempat di Politeknik Transportasi Sungai Danau dan Penyeberangan Palembang dan Pelabuhan Boom Baru Palembang. Waktu penelitian ini selama enam (6) bulan. Dalam penelitian ini penulis menentukan objek yang akan diteliti yaitu sistem pelampung suar lateral dan kardinal. Metode yang digunakan oleh penulis pada penelitian ini adalah metode kualitatif. Metode kualitatif sering juga disebut sebagai metode konstruktif karena dengan metode kualitatif dapat ditemukan data-data yang berserakan, selanjutnya dikonstruksikan dalam satu tema yang lebih bermakna dan mudah dipahami (Sugiyono, 2019:24).

Dalam penelitian kualitatif instrumennya adalah orang atau human instrument yaitu peneliti itu sendiri. Metode kualitatif digunakan untuk mendapatkan data yang mendalam, suatu data yang mengandung makna. Menurut Sugiyono (2019:409) mengatakan bahwa teknik pengumpulan data merupakan langkah yang paling utama dalam penelitian, karena tujuan utama dari penelitian adalah mendapatkan data.

Teknik yang digunakan dalam penelitian ini adalah teknik dokumentasi, teknik pustaka, simak, dan teknik catat. Menurut Sugiyono (2019:430) dokumentasi merupakan catatan peristiwa yang sudah berlalu, dan dokumen bisa berbentuk tulisan, gambar, atau karya-karya monumental dari seseorang.

Hasil penelitian juga akan semakin kredibel apabila didukung oleh foto-foto atau karya tulis akademik dan seni yang telah ada. Dokumen atau dokumentasi merupakan sebuah catatan peristiwa yang sudah berlalu (Sugiyono, 2019:430). Jadi, dapat disimpulkan dokumen atau dokumentasi adalah sebuah catatan yang sudah berlalu.

Metode pengumpulan data yang dipakai pada penelitian ini adalah metode observasi, wawancara, dan studi literatur. Penelitian juga dilaksanakan pada Pelabuhan Boom Baru Palembang dengan metode observasi, wawancara, dan studi literature.

1. Observasi adalah metode atau cara-cara untuk mengamati keadaan yang wajar dan yang sebenarnya tanpa ada usaha yang disengaja untuk mempengaruhi, mengatur, atau memanipulasinya.

2. Wawancara merupakan teknik pengumpulan data yang dilakukan melalui tatap muka dan tanya jawab langsung kepada informan yang berkompeten di bidangnya antara pengumpul data terhadap narasumber/sumber data. 
Surnata, Hayatun Nufus, Kodrat Alam, Elfita Agustini

Semiotika Rambu-Rambu Lalu Lintas Laut

3. Studi literatur adalah salah satu metode pengumpulan data dengan cara membaca buku-buku dan jurnal sesuai dengan data yang dibutuhkan. Pada penelitian ini penulis memilih studi literatur untuk mengumpulkan referensi dari jurnal-jurnal yang memiliki kemiripan dalam pembuatan aplikasi ini.

Uji keabsahan data dalam sebuah penelitian, biasanya hanya ditekankan pada uji validitas. Dalam pengujian keabsahan data penelitian kualitatif meliputi uji validitas internal, validitas eksternal, dan objektivitas (Sugiyono, 2019:488). Validitas data sangat diperlukan dalam sebuah penelitian guna memperkuat keabsahan data yang akan digunakan oleh peneliti, sebab uji validitas merupakan jaminan kebenaran simpulan dari hasil penelitian.

Menurut Sugiyono (2019:485) validitas merupakan derajat ketetapan antara data yang sesungguhnya terjadi pada obyek penelitian dengan data yang dapat dilaporkan oleh peneliti. Dengan demikian data yang valid adalah data yang tidak berbeda antara data yang dilaporkan oleh peneliti dengan data yang sesungguhnya terjadi pada obyek penelitian. Data penelitian kualitatif, temuan atau data dapat dinyatakan valid apabila tidak ada perbedaan antara yang dilaporkan peneliti dengan apa yang sesungguhnya terjadi pada obyek yang diteliti.

\section{Hasil Penelitian dan Pembahasan \\ 1. Hasil Penelitian}

Bagian ini akan disajikan kode-kode visual yang terdapat pada buoyage cardinal dan lateral dengan metode semiotika visual Charles S. Peirse. Hasil analisis data akan melihat tiga aspek (triadic) yaitu sign, object, dan interpretant yang ada di Laut Bangkan, Pelabuhan Boom Baru Palembang sebagai berikut.

a. Deskripsi Cardinal Buoyage

Tabel 1. Deskripsi Cardinal Buoyage

\begin{tabular}{ll}
\hline Sign & \\
Object & Arah kerucut dan warna \\
\hline Interpretant & Tanda utara berupa 2 kerucut hitam \\
dengan kedua ujung menghadap ke atas. \\
Pada bagian bawah berwarna kuning. \\
Tanda puncak: dua kerucut hitam, yang \\
satu di atas yang lain dengan puncaknya \\
dua ke atas. Warna: hitam di atas kuning \\
dibawah Bentuk: menara atau batang \\
Suar.
\end{tabular}

Silampari Bisa: Jurnal Penelitian Pendidikan Bahasa Indonesia, Daerah, dan Asing Vol. 4, No. 2, 2021 
Surnata, Hayatun Nufus, Kodrat Alam, Elfita Agustini

Semiotika Rambu-Rambu Lalu Lintas Laut

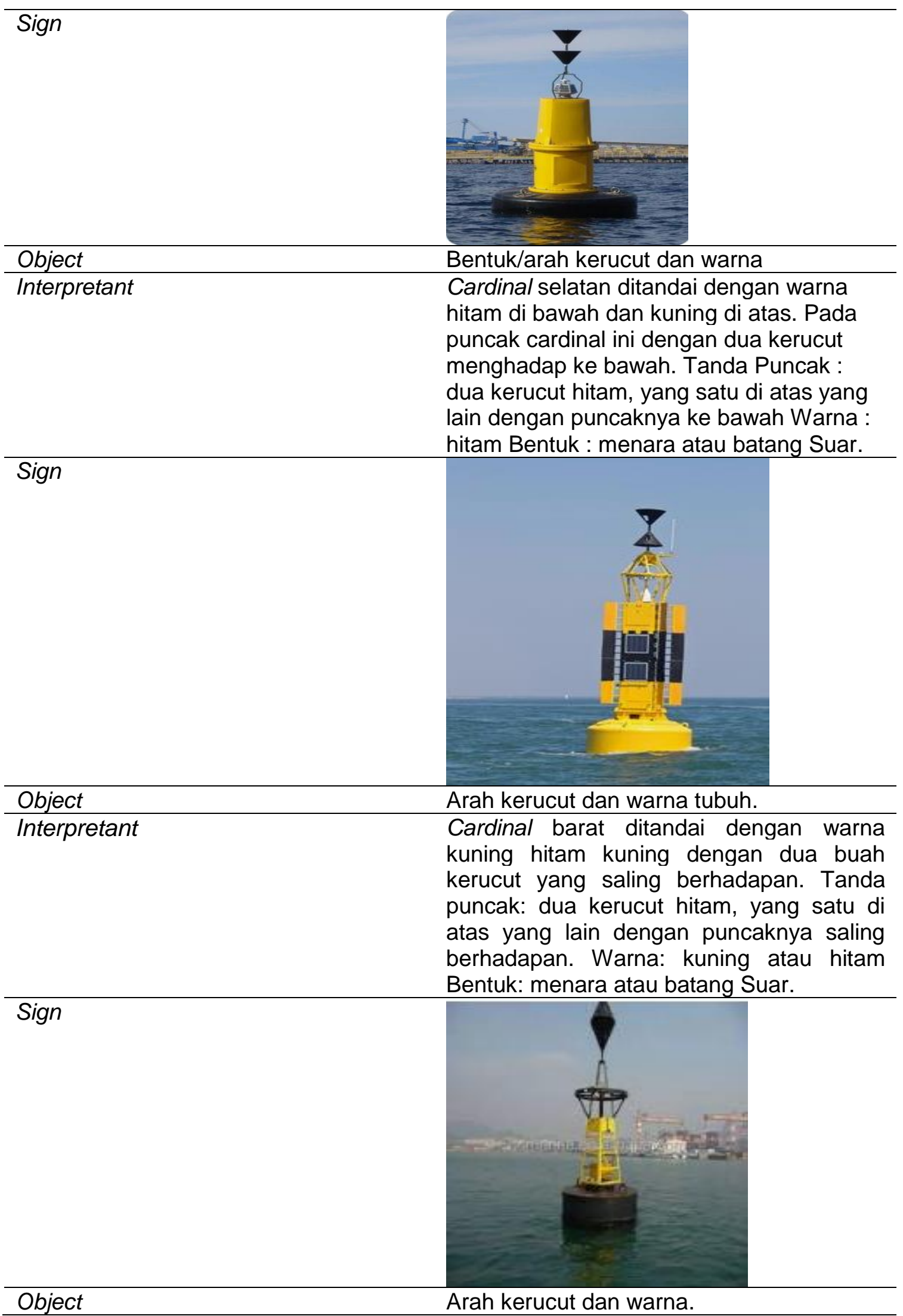

Silampari Bisa: Jurnal Penelitian Pendidikan Bahasa Indonesia, Daerah, dan Asing Vol. 4, No. 2, 2021 
Surnata, Hayatun Nufus, Kodrat Alam, Elfita Agustini

Semiotika Rambu-Rambu Lalu Lintas Laut

Interpretant

Tanda puncak: dua kerucut hitam, yang satu di atas yang lain dengan alasnya saling berhadapan. Warna: hitam Bentuk: menara atau batang Suar.

b. Deskripsi Warna Buoyage Lateral

Lateral merupakan sistem perpelampungan lateral atau sistem perpelampungan yang biasa digunakan di tepi pantai, perairan sempit, perairan pedalaman, atau di pintu masuk pelabuhan. Sistem perpelampungan lateral ini dibedakan atas pelampung sisi kiri dan pelampung sisi kanan. Pelampung pada sisi kanan (starboard hand) ditandai dengan bentuk pelampung yang runcing, berwarna hijau, puncak berbentuk segitiga, dan apabila terdapat suar maka warna penyinarannya adalah hijau cerlang. Pelampung pada sisi kiri (port hand) ditandai dengan bentuk pelampung yang tumpul, berwarna merah, puncak berbentuk kubus atau $\mathrm{T}$, dan apabila terdapat suar maka warna penyinarannya adalah merah cerlang. Berikut deskripsi warna buoyage lateral.

Tabel 2. Deskripsi Warna Buoyage Lateral

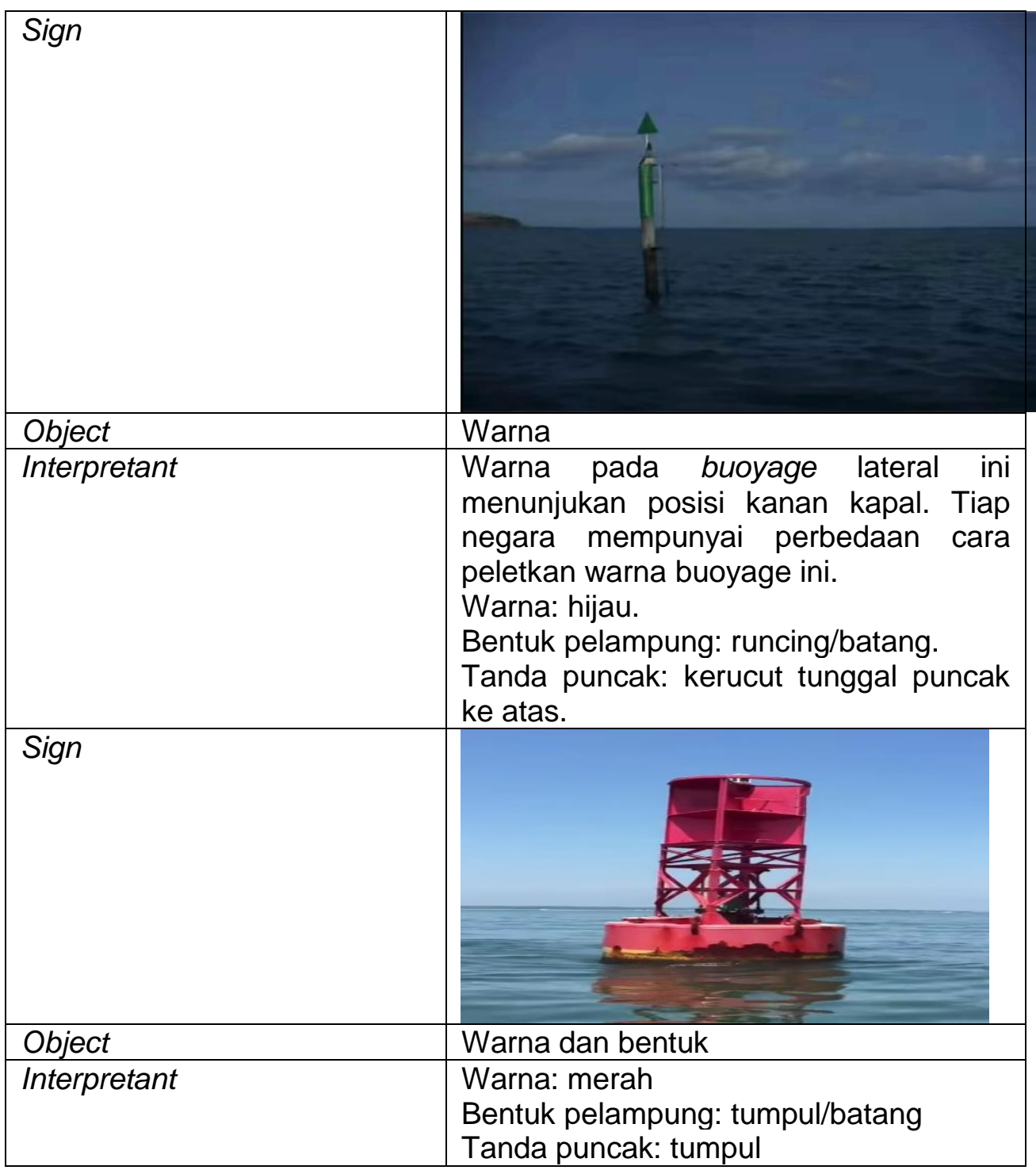

Silampari Bisa: Jurnal Penelitian Pendidikan Bahasa Indonesia, Daerah, dan Asing Vol. 4, No. 2, 2021 
Surnata, Hayatun Nufus, Kodrat Alam, Elfita Agustini

Semiotika Rambu-Rambu Lalu Lintas Laut

\begin{tabular}{|l|l|}
\hline & $\begin{array}{l}\text { Suar jika dilengkapi lampu: warna merah } \\
\text { Nomor kiri genap. }\end{array}$ \\
\hline
\end{tabular}

\section{Pembahasan}

Cardinal Buoy mulai dari warna dan top mark dibuat berdasarkan geografi penduduk bumi (Sanders, 2018). Dunia ini dibagi menjadi 4 bagian yaitu: utara, timur, selatan, dan barat.

a. North Cardinal Buoy/Pelampung Kardinal Utara

Berikut akan dibahas mengenai pelampung cardinal utara, terdapat dua buah kerucut yang kedua ujungnya menghadap ke atas. Pelampung ini terletak sedemikian rupa sehingga perairan aman terletak di bagian utaranya. Tubuh pelampung ini berwarna hitam pada bagian atas dan kuning bagian bawah. Warna hitam pada bagian atas bahwaitu adalah pelampung utaranya. Kerucut pada bagian atasnya menunjukkan arah utara.

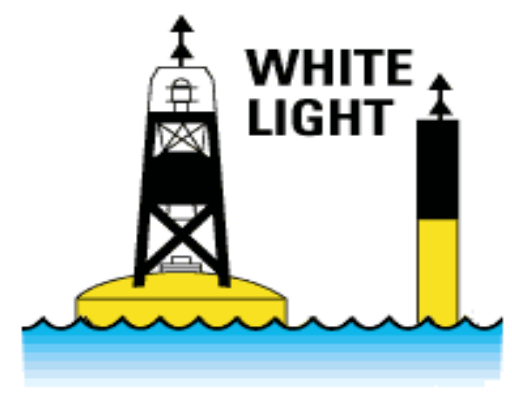

Gambar 1. Cardinal Utara

\section{b. East Cardinal Buoy/Pelampung Kardinal Timur}

Pelampung cardinal timur terletak untuk menunjukkan bahwa perairan teraman adalah di sebelah timurnya. Warna hitam diposisikan di atas dan bagian tengah berwarna kuning dan bagain bawah berwarna hitam. Warna-warna tersebut menunjukkan bahwa itu adalah pelampung timur. Bentuk kerucut di atasnya saling berlawanan arah da itu juga merupakan tanda bahwa itu merupakan cardinal timur.

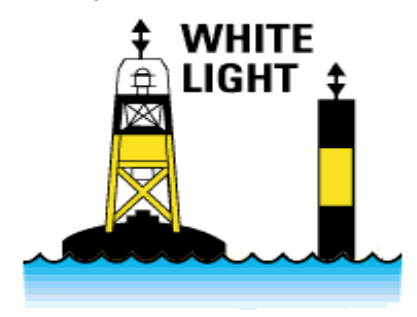

Gambar 2. Pelampung Cardinal Timur

c. West Cardinal Buoy atau Pelampung Cardinal Barat

Pelampung ini terletak untuk menunjukkan bahwa perairan teraman ada di sebelah baratnya. Warna pada tubuh yaitu hitam yang diposisikan di tengah untuk menunjukkan bahwa itu adalah pelampung barat, kuning terletak di atas dan bagian bawah, warna hitam di tengah-tengah. Komposisi warna tersebut 
Surnata, Hayatun Nufus, Kodrat Alam, Elfita Agustini

Semiotika Rambu-Rambu Lalu Lintas Laut

menunjukkan bahwa itu adlaah cardinal barat. Kerucut pada bagian atas saling berhadapan pada sudut masing-masing.

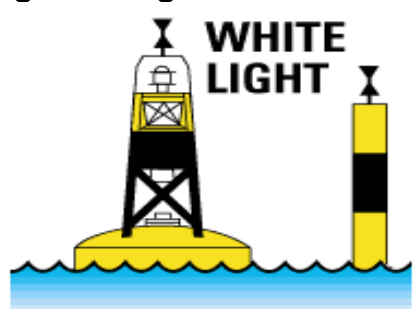

Gambar 3. Pelampung Cardinal Barat

\section{d. South Cardinal Buoy/Pelampung Kardinal Selatan}

Pelampung ini menunjukkan bahwa perairan teraman ada di selatannya. Warna hitam yang terletak pada bagian bawah dan kuning di bagain atas menunjukkan bahwa itu mengarah ke selatan. Bentuk kedua kerucut mengarah ke bawah.

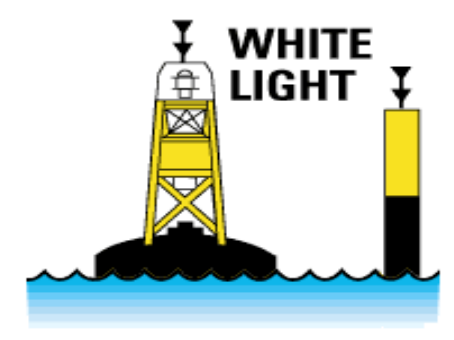

\section{Gambar 4. Cardinal Selatan}

Sistem lateral dipakai di tepi pantai dan perairan yang biasa dilayari diperairan pedalaman, di tempat ada bahasa. Pelampung ini dibedakan atas pelampung sisi kiri dan sisi kanan serta dibedakan atas pelampung sisi kiri dan sisi kanan. Letaknya pun dibedakan atas sektor utara-selatan-barat. Dari bentuk, warna serta letak penempatan cardinal dan lateral berbeda, tetapi tujuan dan makna diletakkannya kedua jenis buoy tersebut tidak berbeda yaitu untuk keselamatan dalam pelayaran.

Simbol warna hijau dan bentuk pada buoy lateral menunjukkan kedudukan pelampung tersebut yaitu pada sisi kanan (starboard hand) dan bentuk pelampung yang runcing atau menyerupai ketupat atau segi tiga.

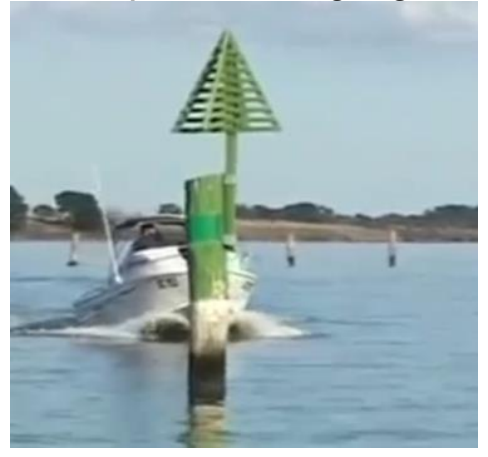

Gambar 5. Starboard Hand 
Pelampung pada sisi kiri (port hand) berbentuk pelampung tumpul atau puncaknya berbentuk kubus. Warna buoy adalah merah. Sebagaimana system IALA bouyage "A" aturan Masuk Keluar Pelabuhan. Saat memasuki pelabuhan (up stream) tanda pelabuhan merah harus di sisi port hand kapal (kiri). Jadi bentuk dan warna buoy lateral menandakan posisi kedua tanda tersebut ketika kapal memasuki pelabuhan.

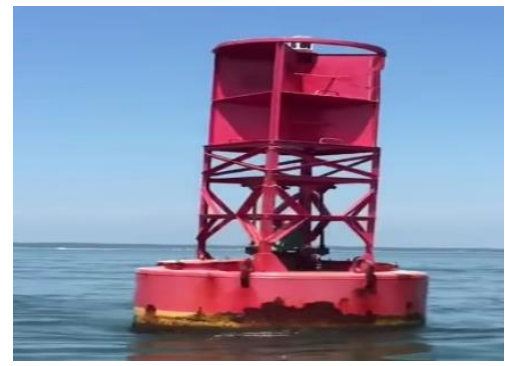

Gambar 6. Bouy Sisi Kiri (Port Hand)

\section{Simpulan dan Saran}

Hasil penelitian ini dapat disimpulkan bahwa makna warna dan bentuk buoy cardinal dan lateral sebagai berikut.

1. Warna yang terdapat pada buoy cardinal dan lateral menunjukkan fungsi dan posisi buoy tersebut seperti warna pada tiang yang berwana kuning pada bagian dan hitam pada bagian bawah atau peletakan warna yang bervariasi. Warna hijau dan merah pada buoy lateral menunjukkan posisi tanda teresebut seperti kiri atau di posisi kanan kapal. Begitupun dengan bentuk cardinal lateral, jika pada bagian atas runcing berarti itu buoy yang berkedudukan di sebelah kanan, jika buoy lateral berbentuk tumpul artinya posisi buoy tersebut berada di sebelah kiri.

2. Warna yang terdapat pada buoy cardinal dan lateral menunjukkan fungsi dan posisi buoy tersebut seperti warna pada tiang yang berwana kuning pada bagian dan hitam pada bagian bawah atau peletakan warna yang bervariasi. Warna hijau dan merah pada buoy lateral menunjukkan posisi tanda tersebut seperti kiri atau di posisi kanan kapal. Begitupun dengan bentuk cardinal lateral, jika pada bagian atas runcing berarti itu buoy yang berkedudukan di sebelah kanan, jika buoy lateral berbentuk tumpul artinya posisi buoy tersebut berada di sebelah kiri.

Hasil penelitian ini memberi kontribusi yang berguna dalam ilmu makna rambu-rambu lalu lintas di laut bagi masyarakat khususnya pelayaran sebagai pengetahuan, penjelasan, serta panduan tentang bagaimana memahami buoy cardinal dan lateral berdasarkan analisis semiotika Charles Sanders Pierce dan bisa dilanjutkan oleh peneliti-peneliti berikutnya. Bagi taruna yang sedang menuntut ilmu agar penelitian bermanfaat dan dapat dijadikan sebagai bahan bacaan tambahan dalam mencari makna perambuan laut khusunya buoy cardinal dan lateral. 
Surnata, Hayatun Nufus, Kodrat Alam, Elfita Agustini

Semiotika Rambu-Rambu Lalu Lintas Laut

\section{Daftar Pustaka}

Emzir \& Rahman, S. (2016). Teori dan Pengajaran Sastra. Jakarta: Rajagrafindo Persada.

Herman. (2017). Teori Semiotika Charles Sander Peirce - Sign - Object Interpretant. https://pakarkomunikasi.com/teori-semiotika-charles-sanderspeirce. Diakses September 2021

Littlejohn, S. W. (2009). Teori Komunikasi Theories of Human Communication Edisi 9. Jakarta. Salemba Humanika.

Nazaruddin, K. (2015). Pengantar Semiotika. Yogyakarta: Graha Ilmu.

Peraturan Menteri Perhubungan Nomor 13 Tahun 2014 tentang Rambu Lalu Lintas. Jakarta: Pemerintah Republik Indonesia.

Ratih, R. (2016). Teori dan Aplikasi Semiotik Michael Riffaterre. Yogyakarta: Pustaka Pelajar.

Rorong, M. J. (2019). Representasi Nilai Kemanusiaan Web Series Kisah Carlo (Analisis Semiotika dalam perspektif Charles Sanders Peirce). Semiotika: Jurnal Komunikasi, 13(1). doi:10.30813/s:jk.v13i1.1792

Rusmana, D. (2014). Filsafat Semiotika Paradigma, Teori, dan Metode Intrepretasi Tanda dari Semiotika Struktural hingga Dekonstruksi Praktis. Bandung: CV Pustaka Setia.

Saleh, R. W. (2018). Edukasi Rambu Lalu Lintas Untuk Anak Melalui Media Permainan Digital "Ingat Rambu" dengan Adobe Flash. CYBERNETICS, 2(1). doi:10.29406/cbn.v2i1.890

Sanders, J. (2018). Cardinal Marks. https://www.boatschool.com.au/cardinalmarks/. Boatschool. Retrieved 9 Oktober 2021

Saribanon, E., Sitanggang, R., \& Amrizal, A. (2017). Kepuasan Pengguna Jasa Transportasi untuk Meningkatkan Loyalitas. Jurnal Manajemen Transportasi dan Logistik, 3(3), 317. doi:10.25292/j.mtl.v3i3.81

Sobur, A. (2004). Semiotika Komunikasi. Bandung: Remaja Rosdakarya.

Sugiyono. (2019). Metode Penelitian Kuantitatif, Kualitatif, dan R\&D. Bandung: Alfabeta.

Syakur, M. A., \& Anamisa, D. R. (2018). Rancang Bangun Aplikasi Pembelajaran Rambu-Rambu Lalu Lintas Berbasis Android. Multitek Indonesia, 12(1), 1. doi:10.24269/mtkind.v12i1.641 
Surnata, Hayatun Nufus, Kodrat Alam, Elfita Agustini

Semiotika Rambu-Rambu Lalu Lintas Laut

Undang-Undang Nomor 22 Tahun 2009 tentang Lalu Lintas dan Angkutan Jalan. Jakarta: Pemerintah Republik Indonesia.

Wahyuni, F. S. (2019). Penerapan Blob (Binary Large Object) Analysis pada Sistem Pengenalan Rambu-Rambu Lalu Lintas. Jurnal Mnemonic, 1(2), 6266. doi:10.36040/mnemonic.v1i2.40

Zaidan, A.R., dkk. (2007). Kamus Istilah Sastra. Jakarta: Balai Pustaka.

Silampari Bisa: Jurnal Penelitian Pendidikan Bahasa Indonesia, Daerah, dan Asing Vol. 4, No. 2, 2021 